3-1973

\title{
What Leads to Modernisation? - A Comment on Research Trends
}

Robert B. Charlick

Cleveland State University, r.charlick@csuohio.edu

Follow this and additional works at: https://engagedscholarship.csuohio.edu/clpolsci_facpub

Part of the Political Theory Commons

How does access to this work benefit you? Let us know!

Publisher's Statement

(C) 1973 Cambridge University Press

\section{Original Citation}

Charlick, R. B. What Leads to Modernisation? - A Comment on Research Trends. The Journal of Modern African Studies, Vol. 11, No. 1 (Mar., 1973), pp. 139-140.

Repository Citation

Charlick, Robert B., "What Leads to Modernisation? - A Comment on Research Trends" (1973). Political Science Faculty Publications. 30.

https://engagedscholarship.csuohio.edu/clpolsci_facpub/30

This Article is brought to you for free and open access by the Political Science Department at EngagedScholarship@CSU. It has been accepted for inclusion in Political Science Faculty Publications by an authorized administrator of EngagedScholarship@CSU. For more information, please contact library.es@csuohio.edu. 


\section{CAMBRIDGE \\ UNIVERSITY PRESS}

What Leads to Modernisation? - A Comment on Research Trends

Author(s): Robert B. Charlick

Reviewed work(s):

Source: The Journal of Modern African Studies, Vol. 11, No. 1 (Mar., 1973), pp. 139-140

Published by: Cambridge University Press

Stable URL: http://www.jstor.org/stable/159878

Accessed: 26/07/2012 18:44

Your use of the JSTOR archive indicates your acceptance of the Terms \& Conditions of Use, available at http://www.jstor.org/page/info/about/policies/terms.jsp

JSTOR is a not-for-profit service that helps scholars, researchers, and students discover, use, and build upon a wide range of content in a trusted digital archive. We use information technology and tools to increase productivity and facilitate new forms of scholarship. For more information about JSTOR, please contact support@jstor.org. 


\title{
What Leads to Modernisation ? - a comment on research trends
}

\author{
by Robert B. Charlick, Department of Political Science, Cleveland State University
}

In a recent issue of this Journal - Vol. Ix, No. 4, December 1972 - Rodolfo Salcedo explores the question of causal sequences in the modernisation process. His article illustrates three serious weaknesses in current research into this problem: (i) the inadequate conception of modernisation as a dependent variable, (ii) the choice of theoretically significant independent variables in discussing paths to modernisation, and (iii) the neglect of political participation as a relevant factor.

Salcedo suggests that modernisation is a dependent state or consequence of other variables, but his first definition is given in such negative and imprecise terms as 'a movement away from traditionalism. In what direction, we do not profess to know.' It is obviously incompatible with the construction of scientific theories of change to have a dependent variable which is incapable of measurement because it is conceptually unclear. Next, he proceeds to provide content for his notion of anti-traditional behaviour by suggesting - in the tradition of Daniel Lerner, The Passing of a Traditional Society: modernisation in the Middle East (New York, 1958) - that 'modern' society is more participatory than 'traditional' society, and that this takes the form of a broadening of economic income distribution and a widening of political participation. He goes on to assume that traditional behaviour is a static and passive orientation towards the world, and that modern man is best characterised by his propensity to innovate or to accept change. Having reduced 'participation' to the reception of new ideas, he then examines the response of 1,346 Eastern Nigerian farmers to six new agricultural practices promoted by the extension service.

There is no justification for the selection of these particular practices, because Salcedo's conception of modernisation is both inappropriate and unworkable. It is not readily apparent that behavioural responses to specific farm 'innovations' can be used as a measure of economic and political participation. But even if it were an appropriate equation, to assume that 'modern' man will be receptive to any new external idea is to reduce him to a pitiable and totally irrational state, and suggests that 'modern' society changes randomly for the sake of change. As anthropologists have demonstrated that societies at all levels of economic development have undergone enormous changes, and that a variety of individual members hold positive attitudes towards change, this particular concept lacks the capacity to discriminate 'modernisation' from all other forms of human change.

It seems preferable to define modernisation as a movement towards a specific pattern of relationships. A fruitful course might then be to simply focus on one typical process, such as 'economic modernisation' which can be given concrete empirical referents, and to reserve the more general term 'modernisation' to the complex of social phenomena which accompany this particular form of economic change. Alternatively, we might accept Lerner's suggestion that 'modernisation' is a state of heightened participation, and define this in terms of specific economic and political behavioural phenomena.

The more interesting question, especially to the student of development, 
is 'What does lead to modernisation?' - although the answer depends upon the definition adopted. Salcedo's investigation of this problem, however, is disappointing to social scientists concerned with modernisation, because he examines only communications factors - urban contact, literacy, mass media exposure - to the exclusion of such theoretically important variables as social structure, political behaviour, and attitudes. His choice of independent variables, moreover, does not reflect a limitation in the codebook data published by Michigan State University's Diffusion of Innovations Center, but rather his personal preferences. Essentially, he restricts himself to the somewhat obvious hypothesis that: 'If an individual is exposed to new ideas, then he will be more likely to accept them.' This approach hardly warrants being elevated to the level of an explanation of 'causes or paths of modernisation'. It is in fact a regrettable approach to a very important question as it can reveal so little about the dynamics of modernising change. Fortunately neither Lerner - who Salcedo purports to follow - nor many other research workers who have investigated this model of modernisation have taken such a confining view. It should be noted here that Lerner addressed himself to the problems of social structure and attitudes of empathy in modernisation; his only causal proposition is his theory of what leads to political modernisation.

From the point of view of a political scientist there is a more fundamental issue which emerges from Salcedo's narrow conception of modernisation and from Lerner's more complex theory. These approaches to the question 'What leads to modernisation?' continue to neglect the rôle of political participation. It is reasonable to ask which independent variables account for the emergence of 'participant' forms of political behaviour, as have several researchers who have investigated Lerner's causal proposition. ${ }^{1}$ But unless we agree that modernisation can be defined as the presence/absence of democratic or 'participatory' political behaviour, these investigations cannot answer the question as to what causes this process.

For most of the developing world, 'modernisation' has a special urgency and significance. It is seen to be the complex of social phenomena which surrounds the process of 'economic modernisation', and entails a specific phase of human history in which scientific methods and inanimate energy begin to dominate as the mode of economic production. Leaders of these states, as well as their development advisors, seek to discover how they can influence the rate of economic modernisation. One of the most powerful tools in producing this specific aspect of modernisation may well be political participation. Therefore it is crucial that social scientists examine the various paths to modernisation from the point of view of correlates and causes of economic development, and these inquiries should include an examination of the rôles played by political participation, social structure, and mass attitudes. This approach not only holds the promise of theoretical interest, but should prove to be extremely relevant to current African problems.

1 Lee Sigelman, Modernisation and the Political System: a critique and preliminary empirical analysis (Beverly Hills, 1971), pp. 9-11, summarises the arguments of D. J. McCrone and C. F. Cnudde, Arthur K. Smith, and Hayward Alker, concerning Lerner's hypothesis of the causes of political modernisation. 